\title{
EFEKTYWNOŚĆ TECHNICZNA, EKONOMICZNA I ŚRODOWISKOWA PRODUKCJI WYBRANYCH PRODUKTÓW ROŚLINNYCH W REGIONACH ROLNICZYCH POLSKI
}

\begin{abstract}
Abstrakt
W artykule przedstawiono regionalne zróżnicowanie efektywności technicznej, ekonomicznej i środowiskowej produkcji pszenicy ozimej, żyta ozimego, jeczmienia jarego, rzepaku ozimego oraz buraków cukrowych. W badaniach wykorzystano dane gromadzone w systemie AGROKOSZTY i Polski FADN. Dla pokazania zmian w wynikach badanych działalności analizie poddano średnie czteroletnie. Miara oceny efektywności technicznej była produkcyjność czynników wytwórczych (pracy, ziemi i kapitału), a efektywności ekonomicznej - wskaźnik opłacalności wyrażajacy relacje wartości produkcji do kosztów ekonomicznych. Natomiast efektywność środowiskowa opisują wskaźniki pokazujące koszt oraz poziom nakładów wpływajacych negatywnie na środowisko, tj. nawozów mineralnych (NPK) i środków ochrony roślin .

Wyniki badań wskazuja na znaczne różnice regionalne. Techniczna efektywność czynników produkcji $w$ gospodarstwach położonych $w$ regionie Wielkopolska i Śląsk oraz Pomorze i Mazury była większa niż na Mazowszu i Podlasiu oraz w regionie Małopolska i Pogórze. Najmniejszym zróżnicowaniem w regionach charakteryzowała się produkcyjność ziemi. Ekonomiczna efektywność produkcji zawierała się w przedziale 97,1-147,5\%. Wskaźnik opłacalności na poziomie 97,1\% zapewniło żyto uprawiane $w$ regionie Matopolska i Pogórze. Jego wysokość oznacza, że koszty ekonomiczne nie zostały w pełni pokryte. Dla pełnego pokrycia kosztów ekonomicznych konieczny bytby wzrost plonu lub ceny ziarna żyta o 4,5\%. Regionalne zróżnicowanie zastosowanej dawki nawozów NPK przy uprawie żyta było 1,4-krotne, a w przypadku pozostałych ziemiopłodów - 1,1-krotne.

Natomiast koszt środków ochrony roślin bardziej różnił się regionalnie. Zróżnicowanie 1,1-krotne odnotowano tylko w odniesieniu do buraków cukrowych, w przypadku pszenicy i jęczmienia było 1,2-krotne, rzepaku ozime-
\end{abstract}


go-1,3-krotne, a żyta-2,3-krotne. W regionie Pomorze i Mazury oraz Wielkopolska i Śląsk koszt środków ochrony roślin oraz nawozów NPK w przeliczeniu na 1 ha uprawy badanych działalności na ogół był wyższy niż w regionie Mazowsze i Podlasie oraz Małopolska i Pogórze.

Słowa kluczowe: techniczna efektywność czynników produkcji, opłacalność produkcji, efektywność środowiskowa, koszty ekonomiczne produktów rolniczych, dochód z zarządzania.

Kody JEL: D24, R11, O33.

\section{Wstęp}

Produkcja roślinna jest niezbędna dla egzystencji człowieka, potrzebna jest do wytworzenia żywności pochodzenia roślinnego i zwierzęcego. O poziomie i strukturze produkcji roślinnej decydują warunki klimatyczno-glebowe i ekonomicznoorganizacyjne (Krasowicz i Kopiński, 2006). Mają one wpływ na regionalne zróżnicowanie struktury zasiewów, intensywności organizacji i intensywności produkcji, wysokości plonów oraz towarowości produkcji (Krasowicz i Kuś, 2006).

Rolnictwo ze względu na charakter produkcji jest silnie powiązane z ziemią i ze środowiskiem naturalnym. Jednak nowoczesny sektor rolny coraz częściej opiera się na kapitale i informacji niż na pozostałych czynnikach produkcji, przewaga konkurencyjna gospodarstw w coraz większym stopniu zależy od czynnika wiedzy, jaką dysponują rolnicy (Coleman i in., 2004). Wiąże się to z funkcjonowaniem na rynku unijnym oraz z możliwością korzystania z wielu instrumentów Wspólnej Polityki Rolnej. Efektywność gospodarowania zależy więc od czynników o charakterze technicznym, produkcyjnym i ekonomicznym, ale także od wiedzy i uzdolnień w zakresie zarządzania (Castle i Becker, 1971).

Efektywność - w ogólnym ujęciu - określana jest jako dodatnia cecha działań dających pozytywny skutek, bez względu na to, czy był on zamierzony (działanie skuteczne i efektywne) czy niezamierzony (działanie efektywne) (Czyżewski i Smędzik, 2010a). W rolnictwie efektywność determinowana jest wieloma czynnikami, kształtują one zarówno poziom produkcji jak i kosztów. Niektóre z nich mają charakter techniczny, a inne są czynnikami o wymiarze ekonomicznym, tj. cenowym (Czyżewski i Smędzik, 2010b). Z punktu widzenia gospodarstwa bardzo ważna jest efektywność ekonomiczna produkcji, definiowana jako różnica między efektami a poniesionymi nakładami. Zapewnia ona możliwość przetrwania na rynku, co jest warunkiem dalszego rozwoju i budowania przewagi w konkurencyjnym otoczeniu.

$\mathrm{W}$ ostatnich latach, obok ekonomicznej efektywności produkcji, w coraz większym stopniu wyznacznikiem konkurencyjności w dłuższej perspektywie czasowej staje się efektywność środowiskowa. Tym bardziej, że przeobrażenia technologiczne i organizacyjne procesów produkcyjnych zachodzące w gospodarstwach rolnych wywierają silny wpływ na jej zmiany. Wyzwaniom konkurencyjności rolnictwo w Polsce stara się sprostać przez zmianę skali i kierunku 
produkcji, ale także poprzez wprowadzanie nowoczesnych technologii zwiększających efektywność produkcji i jednocześnie generujących mniej zanieczyszczeń do środowiska (Jankowiak i Bieńkowski, 2010). W ostatnich latach skutki intensyfikacji rolnictwa są coraz wyraźniej dostrzegane, zarówno w Polsce, jak i w innych krajach. Coraz powszechniejsza jest też świadomość ujemnych następstw nadmiernego nawożenia mineralnego czy stosowania dużych ilości chemicznych środków ochrony roślin (Dincer, 2000; Runowski, 2002; Żak, 2016). Niewłaściwe stosowanie przemysłowych środków produkcji, takich jak nawozy sztuczne i środki ochrony roślin, może prowadzić do zaniku naturalnej flory i fauny, zakłócać gospodarkę wodną i mikroklimat, a w konsekwencji niekorzystnie wpływać na wiele ekosystemów.

W 2013 roku średnio w krajach UE-28 sprzedaż środków ochrony roślin liczona na 1 ha użytków rolnych (UR) wynosiła 2,0 kg substancji aktywnej (s.a.). Pod tym względem Polska i Finlandia zajęły dwunastą pozycję (1,5 kg s.a.). Największą sprzedaż środków ochrony roślin w przeliczeniu na 1 ha UR odnotowano w Holandii (5,8 kg s.a.), Belgii (4,8 kg s.a.), we Włoszech (4,1 kg s.a.) i Hiszpanii (3,0 kg s.a.). Dla porównania, najmniej pestycydów sprzedano w Bułgarii - zaledwie 0,3 kg s.a./ha UR (Zalewski, 2016a). Natomiast zużycie nawozów mineralnych w Polsce jest wysokie, w ostatnich kilkunastu latach przewyższa $100 \mathrm{~kg}$ NPK na 1 ha użytków rolnych. W sezonie 2013/2014 Polska plasowała się na czwartej pozycji wśród krajów UE-28, w których poziom nawożenia przewyższał $100 \mathrm{~kg}$ NPK na 1 ha UR (Belgia i Luksemburg $-183 \mathrm{~kg}$, Niemcy - $144 \mathrm{~kg}$, Chorwacja - $136 \mathrm{~kg}$, Polska - $133 \mathrm{~kg}$, Holandia - 127 kg, Irlandia - $120 \mathrm{~kg}$, Francja - $107 \mathrm{~kg}$, Czechy - $103 \mathrm{~kg}$ ). Poziom nawożenia mineralnego średnio w krajach UE-28 (ale także UE-15 i UE-13) wynosił 90 kg NPK na 1 ha UR (Zalewski, 2016b).

Przy niższym zużyciu plonotwórczych środków chemicznych wyniki produkcyjne ziemiopłodów często są niższe. Spadek plonów może jednak wystąpić i po przekroczeniu optymalnego progu nawożenia. Zdarza się, że większe zużycie środków chemicznych jest ekonomicznie nieuzasadnione, ponieważ występują inne czynniki środowiskowe, które ograniczają plonowanie roślin, np. zakwaszenie gleb, niedobór wody (Popp i Hantos, 2011). W ostatnich latach przebieg pogody znacznie odbiega od uważanego przez dziesiątki lat za „,normalny”. Jednym z głównych problemów stają się straty plonów w wyniku niekorzystnych zjawisk pogodowych, między innymi warunków termicznych, opadów atmosferycznych, częstości i intensywności występowania zjawisk ekstremalnych (Tubiello i in., 2007).

Rolnictwo stoi w obliczu dylematu: konieczne jest zapewnienie określonego poziomu produkcji, a jednocześnie minimalizowanie negatywnego wpływu na środowisko naturalne. Konieczność gospodarowania w sposób chroniący środowisko jest oczywista. Podyktowana została zwiększającą się degradacją użytkowanych rolniczo gleb oraz rosnącym zapotrzebowaniem społeczeństwa na żyw- 
ność o dobrych parametrach jakościowych. Celem badań, których wyniki zaprezentowano w artykule, była ocena regionalnego zróżnicowania w Polsce efektywności technicznej, ekonomicznej i środowiskowej produkcji wybranych gatunków zbóż, rzepaku oraz buraków cukrowych.

\section{Materiał i metoda badań}

W badaniach wykorzystano dane charakteryzujące wybrane działalności produkcji roślinnej zebrane i przetworzone w systemie AGROKOSZTY ${ }^{1}$. Dla zrealizowania celu badań, dane zgromadzone w systemie AGROKOSZTY uzupełniono danymi z bazy Polskiego FADN, a następnie przetworzono zgodnie z opracowaną dla produktów rolniczych metodą rachunku kosztów. Przedmiotem analizy było pięć działalności produkcji roślinnej w czterech latach badań (działalności w badaniach w systemie AGROKOSZTY powtarzają się cyklicznie, $\mathrm{z}$ reguły w odstępach dwu- lub trzyletnich), tzn.:

- pszenica ozima, żyto ozime, rzepak ozimy - w 2006, 2008, 2011 i 2013 roku;

- jęczmień jary - w 2007, 2009, 2011 i 2013 roku;

- buraki cukrowe - w 2005, 2007, 2009 i 2014 roku.

Dla pokazania zmian w wynikach badanych działalności produkcyjnych analizie poddano średnie czteroletnie. Taki sposób ujęcia wyników niweluje wpływ przypadkowych wahań możliwych przy analizie średnich jednorocznych (np. wskutek zmian warunków rynkowych czy pogodowych). Liczba gospodarstw w próbie badawczej działalności, łącznie w latach badań wynosiła od 481 do 722 , odpowiednio w odniesieniu do żyta i jęczmienia. Gospodarstwa te zostały pogrupowane według położenia regionalnego. Podział terytorium Polski na 4 jednostki regionalne (Pomorze i Mazury, Wielkopolska i Śląsk, Mazowsze i Podlasie, Małopolska i Pogórze) wypracowany został w ramach dostosowywania polskiej statystyki do standardów $\mathrm{UE}^{2}$.

\footnotetext{
${ }^{1}$ Badania rolniczych działalności produkcyjnych w systemie AGROKOSZTY prowadzone są w indywidualnych gospodarstwach rolnych wybieranych celowo z próby reprezentatywnej, która znajduje się w polu obserwacji Polskiego FADN. Takie podejście jest stosowane dlatego, aby była możliwość uzupełniania baz danych systemu AGROKOSZTY danymi pochodzącymi z systemu Polski FADN. Dobór gospodarstw do badań każdej działalności produkcyjnej dokonywany jest niezależnie. Warunkiem doboru jest prowadzenie wybranej do badań działalności i określona skala jej produkcji. Gospodarstwa uczestniczące w badaniach położone są na terenie całego kraju, nie stanowią jednak - ze względu na sposób doboru - próby reprezentatywnej dla gospodarstw indywidualnych w Polsce prowadzących określoną działalność, np. uprawiających pszenicę ozimą. Prowadzone badania są w pełni dobrowolne i zawsze wymagają zgody rolnika. W systemie AGROKOSZTY gromadzone są ilościowe i wartościowe dane o poziomie produkcji, poniesionych nakładach i kosztach bezpośrednich w odniesieniu do działalności produkcji roślinnej i zwierzęcej. Dane te zbierane są według jednolitych założeń z precyzyjnie wyznaczonymi standardami i dokładnie określoną metodyką. Pozwalają one na obliczenie nadwyżki bezpośredniej.

${ }^{2}$ Regiony rolnicze obejmują województwa: Pomorze i Mazury - lubuskie, zachodniopomorskie, pomorskie, warmińsko-mazurskie; Wielkopolska i Śląsk - wielkopolskie, kujawsko-pomorskie, dolnośląskie, opolskie; Mazowsze i Podlasie - podlaskie, mazowieckie, łódzkie, lubelskie; Małopolska i Pogórze - świętokrzyskie, śląskie, małopolskie, podkarpackie.
} 
Wyniki badań przedstawiono w układzie tabelarycznym. Wykorzystano analizę poziomą porównując parametry charakteryzujące badane działalności w gospodarstwach położonych w czterech regionach rolniczych. Badaniami objęto przychody, czyli wartość produkcji potencjalnie towarowej, koszty oraz efekty ekonomiczne. Za miernik oceny uzyskanych efektów przyjęto poziom nadwyżki bezpośredniej oraz dochodu z działalności z tytułu zarządzania bez wsparcia dopłat. Sposób obliczania tych kategorii zaprezentowano poniżej:

nadwyżka bezpośrednia bez dopłat = wartość produkcji (przychody) - koszty bezpośrednie

dochód z działalności z tytułu zarządzania bez dopłat = wartość produkcji koszty ekonomiczne.

W literaturze terminem koszty ekonomiczne określane są pełne koszty produkcji (Samuelson i Nordhaus, 1995). W przeprowadzonych badaniach za podstawę uznano rachunek kosztów pełnych. Rolnik ma prawo oczekiwać nie tylko pokrycia kosztów wytworzenia produktów, czyli bezpośrednich i pośrednich, ale także powinien uzyskać zwrot z tytułu zaangażowania własnych czynników produkcji. Klasyczna ekonomia wskazuje na trzy czynniki, tj. pracę, ziemię i kapitał. Ich właściwe wykorzystanie powinno zapewnić rolnikowi dochód z tytułu zarzadzania, czyli wynagrodzenie za zaangażowanie w procesie produkcji posiadanej wiedzy, doświadczenia oraz umiejętności zarządczych. Koszty związane z zaangażowaniem własnych czynników produkcji określane są jako koszty alternatywne. Koszt alternatywny to wartość najlepszej niewybranej alternatywy; zakłada się, że poszczególne dobra mogły zostać wykorzystane w inny sposób, co mogłoby przynieść większą korzyść (dochód). Ten rodzaj kosztów alternatywnych w ujęciu pieniężnym określa się często jako koszty implicite (czyli koszty domniemane), w przeciwieństwie do ewidencjonowanych, czyli faktycznie poniesionych wydatków pieniężnych określanych jako koszty explicite (Milewski, 2008).

Koszty bezpośrednie to składniki, które bez wątpliwości można przypisać do danej działalności produkcyjnej, np. materiał siewny, nawozy, środki ochrony roślin, ubezpieczenie plantacji. Koszty te mają proporcjonalny związek ze skalą produkcji oraz mają bezpośredni wpływ na rozmiar (wielkość i wartość) produkcji. Natomiast koszty pośrednie są wspólne dla całego gospodarstwa. Zaliczamy do nich między innymi koszt energii elektrycznej, paliwa, bieżących remontów maszyn i budynków, amortyzację środków trwałych, podatki. Zgodnie z metodyką stosowaną w systemie AGROKOSZTY, koszty pośrednie gospodarstwa zostały rozdzielone na działalności produkcyjne według udziału wartości produkcji każdej z nich w wartości produkcji gospodarstwa ogółem.

Koszty własnych czynników wytwórczych traktowane są jako koszty alternatywne. Nakłady pracy własnej wyceniono według stawki normatywnej, ustalonej na podstawie przeciętnego $\mathrm{w}$ danym roku poziomu wynagrodzeń pracowników zatrudnionych w całej gospodarce narodowej, wg danych Głównego Urzędu Statystycznego (w kolejnych latach badań godzinowa stawka wynosiła: 
w 2005 r. - 8,66 zł, w 2006 r. - 9,02 zł, w 2007 r. - 9,81 zł, w 2008 r. - 10,74 zł, w 2009 r. - 11,31 zł, w 2011 r. - 12,38 zł, w 2013 r. - 13,79 zł, w 2014 r. 14,29 zł). Za miarę kosztu ziemi przyjęto czynsz dzierżawny. Sposób ustalania wyjściowej kwoty czynszu dzierżawnego opracowano korzystając z zasad określania czynszu dzierżawnego przez Agencję Nieruchomości Rolnych. Zastosowany algorytm uwzględnia rodzaj i klasę gruntu oraz okręg podatkowy zgodnie z zasadami obowiązującymi przy naliczaniu podatku rolnego. Takie podejście oznacza, że duży wpływ na wysokość oszacowanego kosztu ziemi, poza klasą bonitacyjną, ma regionalne położenie gospodarstw, które znalazły się w próbie badawczej poszczególnych działalności produkcyjnych. Czynsz dzierżawny wyrażany jest w jednostkach naturalnych, tj. w dt pszenicy. Ilość jednostek zależy od klasy gleby i okręgu podatkowego. Wartościowo wysokość czynszu określono według średniej ceny skupu pszenicy w kraju (wg danych GUS). Koszt kapitału obejmuje koszt kapitału operacyjnego i trwałego. Za koszt kapitału operacyjnego użytego do produkcji uznano wartość nakładów ponoszonych na obrotowe środki produkcji (np. nasiona, nawozy, środki ochrony roślin, paliwo). Natomiast koszt kapitału trwałego to koszt kapitału zainwestowanego we własne produkcyjne środki trwałe (budynki, maszyny). Koszt kapitału oszacowano według stopy procentowej dla rachunków zdeponowanych w głównych bankach komercyjnych w Polsce (wg GUS). Założono, że kapitał obrotowy był zamrożony na okres 6 miesięcy, a kapitał trwały na 1 rok (Skarżyńska, 2010).

Metody badawcze przyjęte w pracy pozwoliły na ocenę technicznej i ekonomicznej efektywności produkcji badanych produktów. Miarą oceny efektywności technicznej była produkcyjność czynników wytwórczych (wyrażona w jednostkach fizycznych), którą zbadano korzystając z mierników wydajności technicznej. Miernikiem technicznej wydajności ziemi były plony badanych działalności produkcji roślinnej. Miarą technicznej wydajności pracy była wielkość produkcji z 1 ha przypadająca na 1 godzinę poniesionych nakładów pracy (własnej i obcej), a technicznej wydajności środków trwałych - wielkość produkcji przypadająca na 100 zł wartości zaangażowanych środków trwałych. Natomiast za miarę oceny efektywności ekonomicznej przyjęto wskaźnik opłacalności, który oznacza relację wartości produkcji do kosztów ekonomicznych.

Podjęto również próbę określenia efektywności środowiskowej produkcji produktów rolniczych. Wskaźniki efektywności środowiskowej wyrażają koszt oraz poziom nakładów wpływających negatywnie na środowisko. W badaniach wykorzystano:

- zużycie nawozów mineralnych - NPK (w kg) na 1 ha uprawy badanych działalności,

- koszt nawozów mineralnych - NPK na 1 ha uprawy badanych działalności,

- koszt środków ochrony roślin na 1 ha uprawy badanych działalności.

O efektywności środowiskowej świadczy także stosunek osiąganych efektów do nakładów wpływających negatywnie na środowisko. W badaniach za- 
stosowano wskaźnik charakteryzujący techniczną efektywność nawożenia. Obrazuje on stosunek plonu do dawki NPK zastosowanej na 1 ha uprawy badanych działalności produkcji roślinnej.

\section{Wybrane informacje o gospodarstwach, w których prowadzono badania produktów rolniczych}

Wyniki badań wskazują, że powierzchnia użytków rolnych gospodarstw z próby badawczej poszczególnych produktów znacznie różniła się regionalnie. W regionie Pomorze i Mazury oraz Wielkopolska i Śląsk była większa niż na Mazowszu i Podlasiu oraz w regionie Małopolska i Pogórze. Porównując skrajne wielkości, zróżnicowanie wynosiło od 1,9- do 2,4-krotnego. Ma to związek ze strukturą agrarną gospodarstw w wydzielonych regionach. Powierzchnia użytków rolnych była jednym z parametrów, jakie zastosowano przy wyłanianiu jednorodnych regionów rolniczych w Polsce (Skarżyńska i in., 2005).

Zróżnicowana regionalnie była również powierzchnia zajęta pod uprawę badanych ziemiopłodów. W regionie Pomorze i Mazury oraz Wielkopolska i Sląsk była większa niż w dwóch pozostałych. Z badań wynika, że większa powierzchnia sprzyjała spadkowi pracochłonności uprawy, co oznacza, że siła robocza była wykorzystywana bardziej efektywnie. Zmniejszał się także udział pracy własnej w nakładach ogółem.

W gospodarstwach z próby badawczej uprawiających pszenicę ozimą, rzepak ozimy i buraki cukrowe, w strukturze wartości produkcji ogółem udział produkcji roślinnej był równy lub większy od $70 \%$. Oznacza to, że we wszystkich regionach dominowała produkcja roślinna. Natomiast w gospodarstwach uprawiających żyto ozime i jęczmień jary udział w strukturze wartości produkcji roślinnej i zwierzęcej w zasadzie oscylował wokół 50\%. Tylko w gospodarstwach uprawiających jęczmień jary w regionie Małopolska i Pogórze oraz Wielkopolska i Śląsk widoczna jest pewna przewaga produkcji roślinnej. Jej udział wynosił odpowiednio 64,0 i 58,7\% (tabela 1).

Udział wartości produkcji, jaką generowała produkcja żyta i jęczmienia, w wartości produkcji ogółem gospodarstw we wszystkich regionach był zbliżony, zawierał się w granicach $6,1-8,5 \%$. Można więc uznać, że ich znaczenie było podobne. W odniesieniu do pozostałych produktów widoczne są różnice. Znaczenie pszenicy i rzepaku w regionie Małopolska i Pogórze było mniejsze niż w pozostałych (udział wynosił odpowiednio 17,7 i 14,6\%). Natomiast znaczenie uprawy buraków cukrowych najmniejsze było w gospodarstwach położonych w regionie Wielkopolska i Śląsk. Udział w strukturze wartości produkcji gospodarstwa wynosił 16,5\%, podczas gdy w pozostałych regionach zawierał się w przedziale 21,9-24,8\%. Decydowały o tym wyniki działalności badanych, ale także pozostałych prowadzonych w gospodarstwach. Należy dodać, że różnice widoczne są także przy porównaniu działalności między sobą. Udział przychodów z pszenicy, rzepaku i buraków cukrowych w przychodach ogółem gospodarstw był większy aniżeli udział przychodów z uprawy żyta i jęczmienia. 
Tabela 1

Wybrane informacje o gospodarstwach uprawiajacych badane działalności produkcji roślinnej w regionach rolniczych Polski, średnio w latach badań

\begin{tabular}{|c|c|c|c|c|}
\hline Wyszczegónienie & $\begin{array}{l}\text { Pomorze } \\
\text { i Mazury }\end{array}$ & $\begin{array}{c}\text { Wielkopolska } \\
\text { i Śląsk }\end{array}$ & $\begin{array}{l}\text { Mazowsze } \\
\text { i Podlasie }\end{array}$ & $\begin{array}{c}\text { Małopolska } \\
\text { i Pogórze }\end{array}$ \\
\hline & \multicolumn{4}{|c|}{ Pszenica ozima } \\
\hline Liczba gospodarstw w badaniach, razem w latach & 120 & 188 & 161 & 133 \\
\hline Powierzchnia użytków rolnych, ha/gosp. & 101,38 & 79,78 & 52,01 & 64,50 \\
\hline Powierzchnia uprawy, ha/gosp. & 30,17 & 24,28 & 16,71 & 16,24 \\
\hline Cena sprzedaży ziarna, zł/dt & 60,64 & 62,27 & 64,30 & 61,65 \\
\hline Nakłady pracy ogółem, godz./ha & 9,7 & 9,5 & 10,6 & 10,8 \\
\hline w tym: udział nakładów pracy własnej, \% & 91,3 & 83,4 & 88,9 & 92,0 \\
\hline \multicolumn{5}{|l|}{ Udział w strukturze wartości produkcji gosp., \% } \\
\hline - produkcji roślinnej & 80,4 & 72,6 & 72,0 & 70,4 \\
\hline - produkcji zwierzęcej & 18,8 & 26,6 & 26,4 & 28,3 \\
\hline \multirow[t]{2}{*}{ - badanej działalności } & 26,6 & 22,1 & 21,2 & 17,7 \\
\hline & \multicolumn{4}{|c|}{ Żyto ozime } \\
\hline Liczba gospodarstw w badaniach, razem w latach & 133 & 109 & 195 & 44 \\
\hline Powierzchnia użytków rolnych, ha/gosp. & 101,47 & 71,02 & 41,79 & 46,82 \\
\hline Powierzchnia uprawy, ha/gosp. & 16,17 & 11,15 & 7,57 & 7,14 \\
\hline Cena sprzedaży ziarna, zł/dt & 46,55 & 51,59 & 52,54 & 46,44 \\
\hline Nakłady pracy ogółem, godz./ha & 8,0 & 9,9 & 9,4 & 11,6 \\
\hline w tym: udział nakładów pracy własnej, \% & 84,6 & 76,5 & 92,8 & 91,2 \\
\hline \multicolumn{5}{|l|}{ Udział w strukturze wartości produkcji gosp., \% } \\
\hline - produkcji roślinnej & 53,1 & 50,7 & 47,0 & 55,0 \\
\hline - produkcji zwierzęcej & 46,3 & 48,2 & 51,1 & 44,2 \\
\hline \multirow{2}{*}{ - badanej działalności } & 7,3 & 6,3 & 6,3 & 6,1 \\
\hline & \multicolumn{4}{|c|}{ Jeczmień jary } \\
\hline Liczba gospodarstw w badaniach, razem w latach & 144 & 237 & 178 & 163 \\
\hline Powierzchnia użytków rolnych, ha/gosp. & 82,54 & 78,69 & 41,36 & 51,29 \\
\hline Powierzchnia uprawy, ha/gosp. & 12,87 & 12,79 & 7,23 & 8,52 \\
\hline Cena sprzedaży ziarna, zł/dt & 57,13 & 61,11 & 60,29 & 59,60 \\
\hline Nakłady pracy ogółem, godz./ha & 7,8 & 7,7 & 8,9 & 9,7 \\
\hline w tym: udział nakładów pracy własnej, \% & 85,8 & 85,0 & 95,3 & 96,0 \\
\hline \multicolumn{5}{|l|}{ Udział w strukturze wartości produkcji gosp., \% } \\
\hline - produkcji roślinnej & 53,6 & 58,7 & 50,9 & 64,0 \\
\hline - produkcji zwierzęcej & 45,6 & 40,5 & 47,4 & 34,5 \\
\hline \multirow[t]{2}{*}{ - badanej działalności } & 8,2 & 7,3 & 7,6 & 8,5 \\
\hline & \multicolumn{4}{|c|}{ Rzepak ozimy } \\
\hline Liczba gospodarstw w badaniach, razem w latach & 146 & 206 & 122 & 79 \\
\hline Powierzchnia użytków rolnych, ha/gosp. & 107,78 & 82,84 & 56,31 & 75,07 \\
\hline Powierzchnia uprawy, ha/gosp. & 22,01 & 18,82 & 12,22 & 13,69 \\
\hline Cena sprzedaży nasion, zł/dt & 130,85 & 138,43 & 134,84 & 134,83 \\
\hline Nakłady pracy ogółem, godz./ha & 8,9 & 9,4 & 9,8 & 10,4 \\
\hline w tym: udział nakładów pracy własnej, \% & 85,4 & 82,2 & 93,5 & 92,9 \\
\hline \multicolumn{5}{|l|}{ Udział w strukturze wartości produkcji gosp., \% } \\
\hline - produkcji roślinnej & 72,1 & 73,2 & 79,4 & 70,7 \\
\hline - produkcji zwierzęcej & 27,2 & 25,9 & 19,2 & 28,2 \\
\hline \multirow[t]{2}{*}{ - badanej działalności } & 18,2 & 19,9 & 16,4 & 14,6 \\
\hline & \multicolumn{4}{|c|}{ Buraki cukrowe } \\
\hline Liczba gospodarstw w badaniach, razem w latach & 109 & 235 & 156 & 73 \\
\hline Powierzchnia użytków rolnych, ha/gosp. & 90,26 & 80,91 & 44,68 & 46,80 \\
\hline Powierzchnia uprawy, ha/gosp. & 12,24 & 9,59 & 7,34 & 8,12 \\
\hline Cena sprzedaży korzeni, zł/dt & 12,54 & 12,71 & 13,30 & 13,19 \\
\hline Nakłady pracy ogółem, godz./ha & 27,2 & 28,8 & 47,3 & 38,8 \\
\hline w tym: udział nakładów pracy własnej, \% & 65,3 & 64,3 & 90,9 & 70,1 \\
\hline Udział w strukturze wartości produkcji gosp., \% & & & & \\
\hline - produkcji roślinnej & 80,6 & 72,9 & 69,9 & 70,1 \\
\hline - produkcji zwierzęcej & 18,8 & 26,4 & 28,9 & 29,0 \\
\hline - badanej działalności & 21,9 & 16,5 & 22,8 & 24,8 \\
\hline
\end{tabular}

Źródło: Opracowano na podstawie danych systemu AGROKOSZTY i Polski FADN. 
W przypadku zbóż najwyższe ceny za sprzedane ziarno uzyskali rolnicy z Wielkopolski i Śląska oraz Mazowsza i Podlasia. Najwyższą cenę za nasiona rzepaku uzyskano w gospodarstwach położonych w regionie Wielkopolska i Śląsk, a za korzenie buraków cukrowych w dwóch regionach: Mazowsze i Podlasie oraz Małopolska i Pogórze (tabela 1).

\section{Efektywność techniczna czynników produkcji}

Efektywność techniczna odnosi się do konwersji zasobów w określony produkt finalny. Opiera się na technologicznych możliwościach produkcyjnych, tzn. wiąże się z wykorzystaniem zasobów w technologicznie najbardziej wydajny sposób, nie jest natomiast powiązana z poziomem cen i kosztów. Efektywność techniczna jest warunkiem koniecznym do osiągnięcia efektywności ekonomicznej, nie znaczy to jednak, że wszystkie rozwiązania technicznie efektywne są też efektywne ekonomicznie. Efektywność techniczna oznacza, że zwiększenie ilości wytwarzanych produktów bez większego zaangażowania czynników produkcji jest niemożliwe, jest więc jednym z przejawów systemu zarządzania gospodarstwem oraz oceny i pomiaru osiągnięć.

Działalności produkcyjne charakteryzują się tym większą efektywnością techniczną, im większy jest uzyskany efekt produkcyjny przy danym poziomie nakładów oraz zastosowanych czynnikach produkcji.

Rozpatrując techniczną efektywność czynników produkcji zaangażowanych w procesie produkcji, wyraźnie widać regionalne zróżnicowanie produkcyjności ziemi zajętej pod uprawę badanych zbóż, rzepaku oraz buraków cukrowych. Należy jednak zaznaczyć, że spośród analizowanych rodzajów produkcyjności odznaczała się ona najmniejszą skalą zróżnicowania. Zróżnicowanie to, przynajmniej w pewnym stopniu, determinowało położenie regionalne gospodarstw, czyli głównie zastosowana technologia i warunki agroklimatyczne (między innymi nasłonecznienie i uwilgotnienie terenu, liczba dni wegetacji, temperatura). W regionie Wielkopolska i Śląsk oraz Pomorze i Mazury - w porównaniu do dwóch pozostałych - produkcyjność ziemi plasowała się na górnym poziomie. Regiony te odznaczały się szczególną przewagą w przypadku ziemi zajętej pod uprawę pszenicy ozimej, żyta ozimego, rzepaku ozimego oraz buraków cukrowych - tabela 2.

Ze względu na różną pracochłonność uprawy oraz różny poziom uzyskanej produkcji uwidoczniły się pomiędzy regionami znaczne dysproporcje w wydajności pracy. Na wyróżnienie zasługują gospodarstwa położone w regionie Pomorze i Mazury oraz Wielkopolska i Śląsk, w których była ona relatywnie wysoka, natomiast w dwóch pozostałych regionach - znacznie mniejsza. Biorąc pod uwagę skrajne wielkości, zróżnicowanie wydajności pracy poniesionej przy produkcji pszenicy ozimej było 1,2-krotne, jęczmienia jarego i rzepaku ozimego - 1,3-krotne, żyta ozimego - 1,7-krotne, a buraków cukrowych - 1,8-krotne. 
Wydajność środków trwałych również była zróżnicowana regionalnie. Gospodarstwa położone w regionie Mazowsze i Podlasie oraz Małopolska i Pogórze uzyskały słabszy wynik niż jednostki z regionu Pomorze i Mazury oraz Wielkopolska i Śląsk, co świadczy o stosunkowo dużym obciążeniu badanych działalności majątkiem trwałym. Wydajność środków trwałych zaangażowanych przy produkcji pszenicy ozimej, żyta ozimego oraz buraków cukrowych najniższa była w regionie Mazowsze i Podlasie. W porównaniu do najwyższego poziomu (w przypadku zbóż na Pomorzu i Mazurach, a buraków cukrowych w regionie Wielkopolska i Śląsk) była niższa odpowiednio o 32,0; 39,5 i 25,6\%. Natomiast wydajność środków trwałych zaangażowanych przy produkcji jęczmienia jarego oraz rzepaku ozimego ukształtowała się na relatywnie niskim oraz jednakowym poziomie na Mazowszu i Podlasiu oraz w regionie Małopolska i Pogórze. W odniesieniu do najwyższego poziomu w regionie Wielkopolska i Śląsk była niższa odpowiednio o 23,7 i 20,0\% (tabela 2).

Tabela 2

Efektywność techniczna czynników wytwórczych uczestniczacych w procesie produkcji badanych produktów $w$ regionach rolniczych Polski, średnio w latach badań

\begin{tabular}{|c|c|c|c|c|}
\hline Wyszczególnienie & $\begin{array}{l}\text { Pomorze } \\
\text { i Mazury }\end{array}$ & $\begin{array}{l}\text { Wielkopolska } \\
\text { i Śląsk }\end{array}$ & $\begin{array}{l}\text { Mazowsze } \\
\text { i Podlasie }\end{array}$ & $\begin{array}{c}\text { Małopols } \\
\text { i Pogórz }\end{array}$ \\
\hline & \multicolumn{4}{|c|}{ ZIEMI - produkcja w dt na 1 ha uprawy } \\
\hline Pszenica ozima & 57,4 & 57,3 & 52,5 & 53,8 \\
\hline Żyto ozime & 34,3 & 31,3 & 28,1 & 29,1 \\
\hline Jęczmień jary & 37,3 & 43,6 & 40,0 & 42,9 \\
\hline Rzepak ozimy & 28,9 & 32,7 & 28,8 & 27,6 \\
\hline \multirow[t]{2}{*}{ Buraki cukrowe } & 581 & 569 & 572 & 457 \\
\hline & \multicolumn{4}{|c|}{ PRACY - produkcja w dt na 1 godzinę nakładów pracy ogółem } \\
\hline Pszenica ozima & 5,94 & 6,06 & 4,97 & 5,00 \\
\hline Żyto ozime & 4,33 & 3,17 & 2,98 & 2,50 \\
\hline Jęczmień jary & 4,78 & 5,65 & 4,48 & 4,42 \\
\hline Rzepak ozimy & 3,25 & 3,48 & 2,93 & 2,66 \\
\hline Buraki cukrowe & 21,33 & 19,73 & 12,09 & 11,79 \\
\hline
\end{tabular}

ŚRODKÓW TRWAŁYCH - produkcja w dt na 100 zł wartości środków trwałych

$\begin{array}{lllll}\text { Pszenica ozima } & 1,03 & 1,01 & 0,70 & 0,79 \\ \text { Żyto ozime } & 1,24 & 0,99 & 0,75 & 0,85 \\ \text { Jęczmień jary } & 0,94 & 1,14 & 0,87 & 0,87 \\ \text { Rzepak ozimy } & 0,50 & 0,50 & 0,40 & 0,40 \\ \text { Buraki cukrowe } & 5,33 & 5,50 & 4,09 & 5,24\end{array}$

Źródło: Opracowano na podstawie badań własnych. 
Niższą wydajność środków trwałych w regionie Mazowsze i Podlasie oraz Małopolska i Pogórze w pewnym stopniu determinował poziom uzyskanej produkcji, ale czynnikiem decydującym było znacznie większe obciążenie badanych działalności wartością posiadanych budynków i budowli oraz maszyn i środków transportu. Świadczy o tym także ich wartość w przeliczeniu na 1 ha użytków rolnych gospodarstw z próby badawczej (tabela 3).

Tabela 3

Wartość budynków i budowli oraz maszyn i środków transportu (zł/ha UR) $w$ gospodarstwach prowadzacych badane działalności w regionach rolniczych Polski, średnio $w$ latach badań

\begin{tabular}{lcccc}
\hline \multicolumn{1}{c}{ Wyszczególnienie } & $\begin{array}{c}\text { Pomorze } \\
\text { i Mazury }\end{array}$ & $\begin{array}{c}\text { Wielkopolska } \\
\text { i Sląsk }\end{array}$ & $\begin{array}{c}\text { Mazowsze } \\
\text { i Podlasie }\end{array}$ & $\begin{array}{c}\text { Małopolska } \\
\text { i Pogórze }\end{array}$ \\
\hline Pszenica ozima & 6562 & 7820 & 10131 & 9439 \\
Żyto ozime & 5225 & 8573 & 9099 & 7643 \\
Jęczmień jary & 6646 & 7744 & 10632 & 9901 \\
Rzepak ozimy & 6347 & 7857 & 9194 & 8773 \\
Buraki cukrowe & 5656 & 5336 & 7491 & 7575
\end{tabular}

Źródło: Opracowano na podstawie badań własnych.

Wartość budynków i budowli oraz maszyn i środków transportu przypadająca na 1 ha użytków rolnych w grupach gospodarstw uprawiających badane działalności produkcji roślinnej w regionie Mazowsze i Podlasie była najwyższa (wyjątkiem były tylko gospodarstwa uprawiające buraki cukrowe). Drugą pozycję pod względem obciążenia wartością tych środków trwałych zajęły gospodarstwa położone w regionie Małopolska i Pogórze (z wyjątkiem gospodarstw uprawiających żyto ozime). Stan posiadania środków trwałych ujętych wartościowo znacznie mniejszy był w regionie Wielkopolska i Śląsk oraz Pomorze i Mazury.

Ocenia się, że wartość środków trwałych w gospodarstwach przynajmniej w pewnym stopniu ma związek z prowadzeniem produkcji zwierzęcej, która determinuje określony poziom wyposażenia. Dotyczy to zwłaszcza gospodarstw położonych na Mazowszu i Podlasiu, z których wiele specjalizuje się w produkcji mleka i utrzymuje duże stada krów mlecznych. Działalności produkcji roślinnej często są prowadzone dla zabezpieczenia bazy paszowej dla zwierząt, mogą jednak oddziaływać na wyposażenie gospodarstw zarówno w specjalistyczne maszyny, jak i budynki.

Inwestycje w zasoby środków trwałych w gospodarstwach wiążą się z ponoszeniem dużych jednorazowych wydatków, a następnie z obciążeniem prowadzonych działalności produkcyjnych kosztami utrzymania tych środków w gotowości do produkcji. Konsekwencją może być niższa efektywność prowadzonej produkcji. W tej sytuacji w zakres decyzji zwiększających efektyw- 
ność techniczną wpisują się decyzje dotyczące wzrostu skali i specjalizacji produkcji. W tym kontekście należy zauważyć, że powierzchnia uprawy badanych działalności w gospodarstwach z regionu Mazowsze i Podlasie oraz Małopolska i Pogórze była znacznie mniejsza niż na Pomorzu i Mazurach oraz w regionie Wielkopolska i Śląsk.

\section{Efektywność ekonomiczna produkcji}

Efektywność ekonomiczna wywodzi się z zasady racjonalnego gospodarowania i oznacza osiąganie określonych wyników przy możliwie najniższych nakładach (kosztach) albo uzyskiwanie możliwie jak najlepszych wyników z danej ilości nakładów. Efektywność ekonomiczna sięga głębiej niż efektywność techniczna, zależy bowiem od cen czynników wytwórczych. Oznacza to, że coś, co jest technicznie efektywne, może nie być efektywne ekonomicznie. Efektywność ekonomiczna związana jest z optymalną alokacją czynników produkcji. Przykładem może być zmiana relacji między czynnikiem pracy a środków trwałych, która może przyczynić się do obniżenia kosztów, a tym samym wzrostu efektywności prowadzonej produkcji.

W tabeli 4 przedstawiono poziom wartości produkcji potencjalnie towarowej (przychody) z badanych produktów, koszty poniesione na jej wytworzenie, nadwyżkę ekonomiczną pozostającą do dyspozycji rolnika oraz opłacalność produkcji ujętą w postaci relacji. Wyrazem tej relacji jest wskaźnik opłacalności, który obrazuje stopień pokrycia kosztów ekonomicznych przez wartość produkcji. Prezentowane obliczenia wskazują jednocześnie na regionalne różnice poszczególnych kategorii.

Analizując przychody $\mathrm{z}$ badanych produktów i porównując $\mathrm{w}$ regionach maksymalny ich poziom do minimalnego, różnica wynosiła od 5,6\% w przypadku buraków cukrowych do $25,7 \%$ w odniesieniu do jęczmienia jarego. Natomiast analogiczna różnica $\mathrm{w}$ wysokości kosztów ekonomicznych zawierała się w przedziale 5,4-15,2\%, odpowiednio w odniesieniu do jęczmienia jarego i rzepaku ozimego.

Następstwem zróżnicowania wartości produkcji i poniesionych kosztów są różnice w poziomie dochodu. Biorąc pod uwagę nadwyżkę bezpośrednią i dochód z zarządzania bez dopłat, uwagę zwraca prawidłowość, która dotyczy czterech spośród pięciu badanych produktów (wyjątkiem były buraki cukrowe). W regionach, w których zboża i rzepak zapewniły najwyższą nadwyżkę bezpośrednią, najwyższy był także dochód z zarządzania bez dopłat. Oznacza to, że wpływ kosztów pośrednich oraz kosztu czynników produkcji nie był na tyle silny, aby spowodować zmianę. W efekcie nadwyżka bezpośrednia, stanowiąca różnicę między wartością produkcji a kosztami bezpośrednimi, determinowała wysokość dochodu z zarządzania. Uprawa pszenicy ozimej i żyta ozimego pozwoliła na uzyskanie dochodu na najwyższym poziomie w gospodarstwach z regionu Pomorze i Mazury oraz Wielkopolska i Śląsk, natomiast uprawa jęcz- 
mienia jarego w gospodarstwach z regionów: Wielkopolska i Śląsk, Małopolska i Pogórze, a rzepaku ozimego - w regionach Wielkopolska i Śląsk, Mazowsze i Podlasie. W tych regionach najwyższy był również wskaźnik opłacalności produkcji.

W przypadku buraków cukrowych najwyższą nadwyżkę bezpośrednią uzyskali plantatorzy z Mazowsza i Podlasia oraz z regionu Małopolska i Pogórze. Natomiast na poziomie dochodu z tytułu zarządzania widoczna jest zmiana pozycję Mazowsza i Podlasia zajęły gospodarstwa z regionu Pomorze i Mazury. Zadecydowały o tym relatywnie wysokie na Mazowszu i Podlasiu koszty pośrednie oraz koszt czynników produkcji. Na poziom kosztów pośrednich znaczący wpływ miał koszt amortyzacji zaangażowanych środków trwałych, natomiast wysoki koszt czynników produkcji determinował koszt pracy własnej. Wskaźnik opłacalności produkcji buraków cukrowych najwyższy był w regionie Małopolska i Pogórze (147,5\%), a najniższy na Mazowszu i Podlasiu $(136,5 \%)$ - tabela 4.

Uprawa pszenicy, jęczmienia, rzepaku i buraków cukrowych średnio w latach i w próbie badawczej gospodarstw we wszystkich regionach zapewniła nadwyżkę w postaci dochodu z zarządzania. Wyjątkiem było tylko żyto uprawiane w regionie Małopolska i Pogórze, w którym dochód ten nie został zrealizowany, strata wynosiła $41 \mathrm{zt} / \mathrm{ha}$. W tej sytuacji pełne pokrycie kosztu własnych czynników produkcji, tj. pracy, ziemi i kapitału, nie było możliwe. Dla pełnego pokrycia kosztów ekonomicznych konieczny byłby wzrost plonu lub ceny sprzedaży ziarna o 4,5\% (plon powinien wynosić 30,4 dt/ha lub cena - 48,52 zł/dt).

Opłacalność produkcji mierzona relacją wartości produkcji do kosztów ekonomicznych wykazała, że spośród badanych produktów najwyższą opłacalnością charakteryzowała się uprawa buraków cukrowych $(136,5-147,5 \%)$, a najmniejszą - uprawa żyta $(97,1-113,7 \%)$.

Miarą odzwierciedlającą stronę produkcyjną i kosztową badanych produktów jest również wysokość kosztów ekonomicznych, jaka musiała zostać zaangażowana do wytworzenia 1 zł dochodu z działalności z tytułu zarządzania bez dopłat. Zróżnicowanie wyników jest duże, zarówno między produktami jak i regionalne. Koszt wytworzenia w regionach 1 zł dochodu z zarządzania zawierał się $\mathrm{w}$ granicach, w przypadku:

- pszenicy ozimej-3,0-4,0 zł,

- żyta ozimego - 7,3-8,0 zł (bez regionu Małopolska i Pogórze),

- jęczmienia jarego - 2,7-6,8 zł,

- rzepaku ozimego - 2,9-4,8 zł,

- buraków cukrowych - 2,1-2,7 zł.

Koszt wytworzenia 1 zł dochodu z zarządzania najwyższy był w przypadku uprawy żyta, a najniższy - buraków cukrowych. Natomiast największe zróżnicowanie $\mathrm{w}$ regionach, porównując skrajne poziomy tego kosztu, odnotowano w przypadku jęczmienia (2,5-krotne), a najmniejsze - żyta (1,1-krotne) - tabela 4. 
Tabela 4

Efektywność ekonomiczna produkcji badanych produktów w regionach rolniczych Polski, średnio w latach badań

\begin{tabular}{|c|c|c|c|c|}
\hline Wyszczególnienie & $\begin{array}{l}\text { Pomorze } \\
\text { i Mazury }\end{array}$ & $\begin{array}{l}\text { Wielkopolska } \\
\text { i Śląsk }\end{array}$ & $\begin{array}{l}\text { Mazowsze } \\
\text { i Podlasie }\end{array}$ & $\begin{array}{c}\text { Małopolska } \\
\text { i Pogórze }\end{array}$ \\
\hline & \multicolumn{4}{|c|}{ Pszenica ozima } \\
\hline Wartość produkcji (WP), zł/ha & 3541 & 3610 & 3442 & 3337 \\
\hline Koszty ekonomiczne (KE), zł/ha & 2662 & 2821 & 2755 & 2660 \\
\hline z tego: koszty bezpośrednie & 1190 & 1253 & 1158 & 1184 \\
\hline koszty pośrednie & 1090 & 1162 & 1178 & 1064 \\
\hline koszt czynników produkcji & 382 & 406 & 419 & 412 \\
\hline Nadwyżka bezpośrednia bez dopłat, zł/ha & 2351 & 2357 & 2284 & 2153 \\
\hline Dochód z zarządzania bez dopłat, zł/ha & 879 & 790 & 687 & 677 \\
\hline \multirow[t]{2}{*}{ Wskaźnik opłacalności (WP/KE), \% } & 133,0 & 128,0 & 124,9 & 125,5 \\
\hline & \multicolumn{4}{|c|}{ Żyto ozime } \\
\hline Wartość produkcji (WP), zł/ha & 1640 & 1637 & 1448 & 1371 \\
\hline Koszty ekonomiczne (KE), zł/ha & 1451 & 1440 & 1287 & 1412 \\
\hline z tego: koszty bezpośrednie & 635 & 659 & 478 & 540 \\
\hline koszty pośrednie & 589 & 549 & 577 & 593 \\
\hline koszt czynników produkcji & 227 & 231 & 232 & 279 \\
\hline Nadwyżka bezpośrednia bez dopłat, zł/ha & 1005 & 978 & 969 & 831 \\
\hline Dochód z zarządzania bez dopłat, zł/ha & 189 & 197 & 161 & -41 \\
\hline \multirow[t]{2}{*}{ Wskaźnik opłacalności (WP/KE), \% } & 113,0 & 113,7 & 112,5 & 97,1 \\
\hline & \multicolumn{4}{|c|}{ Jęczmień jary } \\
\hline Wartość produkcji (WP), zł/ha & 2119 & 2663 & 2424 & 2590 \\
\hline Koszty ekonomiczne (KE), zł/ha & 1848 & 1944 & 1844 & 1928 \\
\hline z tego: koszty bezpośrednie & 833 & 860 & 795 & 798 \\
\hline koszty pośrednie & 762 & 764 & 746 & 768 \\
\hline koszt czynników produkcji & 254 & 320 & 303 & 362 \\
\hline Nadwyżka bezpośrednia bez dopłat, zł/ha & 1286 & 1803 & 1629 & 1792 \\
\hline Dochód z zarządzania bez dopłat, zł/ha & 271 & 719 & 580 & 662 \\
\hline \multirow[t]{2}{*}{ Wskaźnik opłacalności (WP/KE), \% } & 114,6 & 137,0 & 131,5 & 134,3 \\
\hline & \multicolumn{4}{|c|}{ Rzepak ozimy } \\
\hline Wartość produkcji (WP), zł/ha & 3697 & 4403 & 3836 & 3875 \\
\hline Koszty ekonomiczne (KE), zł/ha & 3059 & 3298 & 2862 & 3036 \\
\hline z tego: koszty bezpośrednie & 1571 & 1576 & 1300 & 1377 \\
\hline koszty pośrednie & 1139 & 1331 & 1211 & 1254 \\
\hline koszt czynników produkcji & 350 & 391 & 351 & 405 \\
\hline Nadwyżka bezpośrednia bez dopłat, zł/ha & 2126 & 2827 & 2536 & 2499 \\
\hline Dochód z zarządzania bez dopłat, zł/ha & 638 & 1105 & 974 & 840 \\
\hline \multirow[t]{2}{*}{ Wskaźnik opłacalności (WP/KE), \% } & 120,9 & 133,5 & 134,0 & 127,7 \\
\hline & \multicolumn{4}{|c|}{ Buraki cukrowe } \\
\hline Wartość produkcji (WP), zł/ha & 7241 & 7086 & 7482 & 7127 \\
\hline Koszty ekonomiczne (KE), zł/ha & 5067 & 4957 & 5481 & 4832 \\
\hline z tego: koszty bezpośrednie & 2465 & 2320 & 2459 & 2282 \\
\hline koszty pośrednie & 2158 & 2209 & 2399 & 2014 \\
\hline koszt czynników produkcji & 445 & 428 & 623 & 536 \\
\hline Nadwyżka bezpośrednia bez dopłat, zł/ha & 4776 & 4766 & 5023 & 4845 \\
\hline Dochód z zarządzania bez dopłat, zł/ha & 2173 & 2129 & 2001 & 2294 \\
\hline Wskaźnik opłacalności (WP/KE), \% & 142,9 & 142,9 & 136,5 & 147,5 \\
\hline
\end{tabular}

Źródło: Opracowano na podstawie badań własnych. 


\section{Efektywność środowiskowa}

W przeprowadzonych badaniach podstawową miarą efektywności środowiskowej było zużycie lub koszt wprowadzonych do środowiska, w wyniku świadomej działalności człowieka, nawozów mineralnych i środków ochrony roślin. Miarą dodatkową była techniczna efektywność zastosowanego nawożenia.

Koszt nawozów mineralnych i środków ochrony roślin są składnikami wyraźnie dominującymi w strukturze kosztów bezpośrednich. W przypadku badanych produktów ujętych regionalnie, ich łączny udział wynosił od 67,0 do $83,7 \%$. Zróżnicowanie kosztu nawozów mineralnych w regionach wynikało głównie z różnic w wielkości zastosowanej dawki NPK, chociaż wpływ miała także struktura rodzajowa zastosowanych nawozów oraz cena ich zakupu. Natomiast przyczyną zróżnicowania kosztu środków ochrony roślin (pestycydów) mogła być różnica w cenie zakupu tych środków, jednak ocenia się, że decydujący wpływ miała liczba wykonanych zabiegów ochronnych, co miało związek z ilością zużytej substancji czynnej.

Biorąc pod uwagę wielkości skrajne, regionalne zróżnicowanie dawki NPK zastosowanej przy uprawie żyta było 1,4-krotne, a w przypadku pozostałych ziemiopłodów - 1,1-krotne. Badania wykazały, że w regionie Pomorze i Mazury oraz Wielkopolska i Śląsk najwyższe nawożenie zastosowano pod uprawę żyta, jęczmienia jarego i rzepaku ozimego. Na Mazowszu i Podlasiu wysokie było nawożenie pszenicy ozimej (261 kg/ha), a w regionie Małopolska i Pogórze - buraków cukrowych (390 kg/ha). Natomiast najniższe nawożenie zastosowali rolnicy uprawiający pszenicę ozimą oraz jęczmień jary i rzepak ozimy w regionie Małopolska i Pogórze (wynosiło ono odpowiednio 239, 159 i $299 \mathrm{~kg} / \mathrm{ha}$ ) - tabela 5 .

Regionalne zróżnicowanie kosztu dawki NPK zastosowanej na 1 ha uprawy pszenicy ozimej i buraków cukrowych było 1,1-krotne, podczas gdy w przypadku uprawy jęczmienia jarego i rzepaku ozimego - 1,2-krotne, a żyta - 1,3-krotne. $\mathrm{Z}$ badań wynika, że koszt środków ochrony roślin również różnił się regionalnie. Zróżnicowanie 1,1-krotne odnotowano tylko w odniesieniu do buraków cukrowych. W przypadku pszenicy i jęczmienia zróżnicowanie było 1,2-krotne, rzepaku ozimego - 1,3-krotne, a żyta - 2,3-krotne.

Pod względem wysokości kosztu środków ochrony roślin - podobnie jak w przypadku kosztu NPK - wyróżnia się region Pomorze i Mazury oraz Wielkopolska i Śląsk. W obu regionach najwyższy koszt środków ochrony roślin poniesiono w przypadku uprawy żyta, rzepaku ozimego i buraków cukrowych, natomiast rolnicy z Wielkopolski i Śląska także przy uprawie pszenicy ozimej i jęczmienia jarego. Koszt środków ochrony roślin był najniższy na Mazowszu i Podlasiu w gospodarstwach uprawiających pszenicę ozimą, żyto i buraki cukrowe, a w regionie Małopolska i Pogórze - rzepak ozimy. 
Tabela 5

Efektywność środowiskowa produkcji badanych produktów w regionach rolniczych Polski, średnio w latach badań

\begin{tabular}{|c|c|c|c|c|}
\hline Wyszczególnienie & $\begin{array}{l}\text { Pomorze } \\
\text { i Mazury }\end{array}$ & $\begin{array}{c}\text { Wielkopolska } \\
\text { i Śląsk }\end{array}$ & $\begin{array}{l}\text { Mazowsze } \\
\text { i Podlasie }\end{array}$ & $\begin{array}{c}\text { Małopolska } \\
\text { i Pogórze }\end{array}$ \\
\hline & \multicolumn{4}{|c|}{ Zużycie NPK na 1 ha uprawy (w kg) } \\
\hline Pszenica ozima & 251 & 254 & 261 & 239 \\
\hline Żyto ozime & 143 & 158 & 115 & 124 \\
\hline Jęczmień jary & 177 & 177 & 175 & 159 \\
\hline Rzepak ozimy & 328 & 339 & 307 & 299 \\
\hline \multirow[t]{2}{*}{ Buraki cukrowe } & 371 & 362 & 383 & 390 \\
\hline & \multicolumn{4}{|c|}{ Koszt NPK na 1 ha uprawy (w zl) } \\
\hline Pszenica ozima & 641 & 664 & 662 & 618 \\
\hline Żyto ozime & 387 & 399 & 304 & 338 \\
\hline Jęczmień jary & 522 & 522 & 490 & 453 \\
\hline Rzepak ozimy & 857 & 882 & 752 & 807 \\
\hline \multirow[t]{2}{*}{ Buraki cukrowe } & 933 & 943 & 963 & 898 \\
\hline & \multicolumn{4}{|c|}{ Techniczna efektywność nawożenia (produkcja w kg na 1 kg NPK) } \\
\hline Pszenica ozima & 23,2 & 22,7 & 20,3 & 22,6 \\
\hline Żyto ozime & 24,4 & 21,1 & 24,7 & 24,4 \\
\hline Jęczmień jary & 21,1 & 24,7 & 22,9 & 27,5 \\
\hline Rzepak ozimy & 8,9 & 9,6 & 9,4 & 9,2 \\
\hline \multirow[t]{2}{*}{ Buraki cukrowe } & 159,7 & 157,3 & 152,9 & 151,9 \\
\hline & \multicolumn{4}{|c|}{ Koszt środków ochrony roślin na 1 ha uprawy (w zl) } \\
\hline Pszenica ozima & 297 & 313 & 272 & 304 \\
\hline Żyto ozime & 100 & 110 & 47 & 64 \\
\hline Jęczmień jary & 124 & 142 & 138 & 133 \\
\hline Rzepak ozimy & 421 & 394 & 336 & 315 \\
\hline Buraki cukrowe & 535 & 493 & 469 & 475 \\
\hline
\end{tabular}

Źródło: Opracowano na podstawie badań własnych.

W badaniach ocenie poddano także techniczną efektywność nawożenia zastosowanego przy uprawie badanych ziemiopłodów. Według literatury, zależność między wielkością plonu roślin a dawką składnika nawozowego jest bardzo skomplikowana i uzależniona od wielu czynników (np. przedplon, warunki glebowe i jej zasobność, odczyn gleby, ilość i rozkład opadów, liczba i wielkość dawek nawozów oraz termin ich stosowania, stosunek składników nawozowych $\mathrm{N}: \mathrm{P}: \mathrm{K})$. Pewien poziom plonu można uzyskać również bez nawożenia - jest to efekt naturalnej żyzności ziemi. Ten sam efekt plonu można uzyskać przy zasto- 
sowaniu odpowiedniej lub nawet kilka razy większej dawki nawozów. Nawożenie, zamiast efektu pozytywnego, może spowodować także spadek plonu (Gębska i Filipiak, 2006).

Wyniki badań wskazują na różnice w technicznej efektywności nawożenia $\mathrm{w}$ regionach, a ponadto najczęściej na brak bezpośredniego powiązania z zastosowaną dawką NPK. Tylko w gospodarstwach uprawiających rzepak ozimy w regionie Wielkopolska i Śląsk, gdzie nawożenie było najwyższe, najwyższa była również jego efektywność techniczna - 9,6 kg nasion na $1 \mathrm{~kg}$ NPK (w pozostałych regionach zawierała się $\mathrm{w}$ granicach $8,8-9,4 \mathrm{~kg}$ ). W przypadku pozostałych produktów nie stwierdzono takiej zależności. Na Mazowszu i Podlasiu dawka NPK zastosowana pod uprawę pszenicy ozimej była najwyższa $(261 \mathrm{~kg} / \mathrm{ha})$, podczas gdy techniczna efektywność nawożenia - najniższa $(20,1 \mathrm{~kg}$ ziarna na $1 \mathrm{~kg}$ NPK). Dotyczyło to także uprawy żyta, jęczmienia oraz buraków cukrowych. Można przypuszczać, że przyczynił się do tego niekorzystny układ innych czynników oddziałujących w agrosystemie.

\section{Podsumowanie}

Powierzchnia zajęta pod uprawę badanych ziemiopłodów, tj. pszenicy ozimej, żyta ozimego, jęczmienia jarego, rzepaku ozimego i buraków cukrowych, różniła się regionalnie. W gospodarstwach położonych w regionie Pomorze i Mazury oraz Wielkopolska i Sląsk była większa niż na Mazowszu i Podlasiu i Małopolsce i Pogórzu. Większa powierzchnia uprawy sprzyjała spadkowi pracochłonności, co oznacza, że siła robocza była wykorzystywana bardziej efektywnie. Sytuacja ta miała wpływ na wydajność techniczną (produkcyjność) czynnika pracy.

Badanie technicznej efektywności czynników produkcji, tj. ziemi, pracy i środków trwałych zaangażowanych w procesie produkcji, wykazało różnice w regionach. Najmniejszą skalą zróżnicowania charakteryzowała się produkcyjność ziemi. Różnice te, przynajmniej częściowo, determinowało położenie gospodarstw, czyli przede wszystkim zastosowana technologia i warunki agroklimatyczne. W regionie Wielkopolska i Śląsk oraz Pomorze i Mazury produkcyjność ziemi była większa niż w dwóch pozostałych. Szczególną przewagę na korzyść tych regionów - odnotowano w przypadku ziemi zajętej pod uprawę pszenicy ozimej, żyta, rzepaku ozimego oraz buraków cukrowych. Pod względem technicznej wydajności pracy na wyróżnienie również zasługują gospodarstwa położone w regionie Wielkopolska i Śląsk oraz Pomorze i Mazury. Zadecydowała o tym niższa pracochłonność uprawy oraz najczęściej wyższa produkcyjność ziemi. Wydajność zaangażowanych w procesie produkcji środków trwałych także była wyższa w tych regionach. Gospodarstwa położone na Mazowszu i Podlasiu i Małopolsce i Pogórzu uzyskały słabszy wynik. Przyczynił się do tego niższy poziom uzyskanej produkcji, ale głównym czynnikiem było większe obciążenie stanem posiadanych środków trwałych (ujętych wartościo- 
wo). Ocenia się, że - przynajmniej w pewnym stopniu - ma to związek z prowadzeniem produkcji zwierzęcej, która determinuje określony poziom wyposażenia gospodarstw. Dotyczy to zwłaszcza jednostek położonych na Mazowszu i Podlasiu, z których wiele specjalizuje się w produkcji mleka.

Badania, których celem była ocena ekonomicznej efektywności produkcji, wykazały, że uprawa pszenicy ozimej i żyta ozimego pozwoliła na uzyskanie nadwyżki bezpośredniej i dochodu $\mathrm{z}$ zarzadzania bez dopłat na najwyższym poziomie w gospodarstwach regionu Pomorze i Mazury oraz Wielkopolska i Śląsk, natomiast uprawa jęczmienia jarego w regionach: Wielkopolska i Śląsk, Małopolska i Pogórze, a rzepaku ozimego - Wielkopolska i Śląsk, Mazowsze i Podlasie. Wskaźnik opłacalności produkcji w tych regionach również był najwyższy. Oznacza to, że pewnego rodzaju wyznacznikiem opłacalności na poziomie dochodu z zarządzania był poziom nadwyżki bezpośredniej. W przypadku buraków cukrowych sytuacja była odmienna. Najwyższą nadwyżkę bezpośrednią uzyskali plantatorzy z Mazowsza i Podlasia oraz z Małopolski i Pogórza. Natomiast na poziomie dochodu z zarządzania pozycję Mazowsza i Podlasia zajęły gospodarstwa z regionu Pomorze i Mazury. Zadecydowały o tym relatywnie wysokie na Mazowszu i Podlasiu koszty pośrednie oraz wysoki koszt czynników produkcji. Na poziom kosztów pośrednich znaczący wpływ miał koszt amortyzacji zaangażowanych środków trwałych, natomiast koszt czynników produkcji determinował koszt pracy własnej. Tylko uprawa żyta w regionie Małopolska i Pogórze nie zapewniła nadwyżki w postaci dochodu z tytułu zarzadzania bez dopłat, strata wynosiła 41 zł/ha. Wskaźnik opłacalności produkcji, który wyraża relację wartości produkcji do kosztów ekonomicznych wynosił $97,1 \%$. Biorąc pod uwagę wszystkie działalności, w ujęciu regionalnym wskaźnik ten zawierał się w przedziale 97,1-147,5\%.

Miarą oceny efektywności środowiskowej produkcji badanych produktów było zużycie lub koszt wprowadzonych do środowiska nawozów mineralnych i środków ochrony roślin. Z badań wynika, że w regionie Pomorze i Mazury oraz Wielkopolska i Śląsk najwyższe nawożenie zastosowano pod uprawę żyta, jęczmienia jarego i rzepaku ozimego. Na Mazowszu i Podlasiu wysokie było nawożenie pszenicy ozimej, a w regionie Małopolska i Pogórze - buraków cukrowych. Pomimo różnic, regionalne zróżnicowanie zastosowanej dawki NPK najczęściej nie było duże, przy uprawie żyta było 1,4-krotne, a w przypadku pozostałych ziemiopłodów - 1,1-krotne. Natomiast koszt środków ochrony roślin znacznie różnił się regionalnie. Zróżnicowanie 1,1-krotne odnotowano tylko w odniesieniu do buraków cukrowych, w przypadku pszenicy i jęczmienia było 1,2-krotne, rzepaku ozimego - 1,3-krotne, a żyta - 2,3-krotne. Relatywnie wysoki koszt środków ochrony roślin odnotowano w gospodarstwach regionu Pomorze i Mazury oraz Wielkopolska i Śląsk. W obu regionach najwyższy koszt poniesiono w przypadku uprawy żyta, rzepaku ozimego i buraków cukrowych, natomiast rolnicy z Wielkopolski i Śląska także przy uprawie pszenicy 
ozimej i jęczmienia jarego. Koszt środków ochrony roślin był najniższy na Mazowszu i Podlasiu w gospodarstwach uprawiających pszenicę ozimą, żyto i buraki cukrowe, a w regionie Małopolska i Pogórze - rzepak ozimy.

Integracja europejska oraz globalizacja stymulują wiele zmian w rolnictwie polskim. Szansę na utrzymanie się na rynku mają rolnicy, którzy sprostają wyzwaniu obniżania kosztów produkcji, zwiększaniu skali i efektywności produkcji oraz poprawie jakości wytwarzanych produktów. W sektorze rolnym efekty produkcyjne często związane są $\mathrm{z}$ równoczesnym powstawaniem różnego rodzaju zagrożeń środowiskowych, np. powszechne stosowanie pestycydów przyczynia się do występowania wielu chorób, może również wpływać na zdrowie przyszłych pokoleń (Żak, 2016). Społeczne obawy budzi także stosowanie dużych dawek nawozów mineralnych. Wyzwaniem dla współczesnego rolnictwa jest zapewnienie bezpieczeństwa żywnościowego, lecz działania $\mathrm{w}$ tym zakresie powinny mieć charakter przyjazny środowisku naturalnemu. Czynnikiem intensyfikującym produkcję rolniczą, który jednocześnie jest nieszkodliwy dla środowiska, jest wprowadzanie nowych odmian roślin uprawnych, bardziej plennych i lepszych jakościowo (odpornych na choroby i szkodniki). Powinna być również doskonalona technologia uprawy, uwzględniająca nie tylko efekty produkcyjne i ekonomiczne, ale także bezpieczeństwo środowiska przyrodniczego. 


\section{Literatura:}

Castle, E.N., Becker, M.H. (1971). Zasady podejmowania decyzji w gospodarstwie rolniczym. Warszawa: PWRiL, s. 19.

Coleman, W., Grant, W., Josling, T. (2004). Agriculture in New Global Economy. Wyd. Edward Elgar, Cheltencham-Northampton, s. 51.

Czyżewski, A., Smędzik, K. (2010a). Efektywność techniczna i środowiskowa gospodarstw rolnych w Polsce według typów i klas wielkości w latach 2006-2008. Rocz. Nauk Rol., SERiA G, t. 97, z. 3, s. 61-71, za: Pszczółkowski, T. (1978). Mała encyklopedia prakseologii i teorii organizacji. Wrocław: Zakład Narodowy im. Ossolińskich, s. 60.

Czyżewski, A., Smędzik, K. (2010b). Efektywność techniczna i środowiskowa gospodarstw rolnych w Polsce według typów i klas wielkości w latach 2006-2008. Rocz. Nauk Rol., SERiA G, t. 97, z. 3, s. 61-71.

Dincer, I. (2000). Renewable energy and sustainable development: a crucial review. Renewable and Sustainable Energy Reviews, 4, s. 157-175.

Gębska, M., Filipiak, T. (2006). Podstawy ekonomiki i organizacji gospodarstw rolniczych. Warszawa: SGGW, s. 59-65.

Jankowiak, J., Bieńkowski, J. (2010). Syntetyczna ocena stanu zrównoważenia produkcyjnego, środowiskowego i ekonomicznego rolnictwa w skali gospodarstwa i regionu. W: Wilkin, J. (red.) (2010). Wielofunkcyjność rolnictwa. Kierunki badań, podstawy metodologiczne i implikacje praktyczne. Warszawa: IRWiR PAN, s. 93-112.

Krasowicz, S., Kopiński, J. (2006). Wpływ warunków przyrodniczych i organizacyjno-ekonomicznych na regionalne zróżnicowanie rolnictwa w Polsce. W: Regionalne zróżnicowanie produkcji rolniczej w Polsce. Program Wieloletni 2005-2010, IUNG-PIB, nr 3, s. 81-99.

Krasowicz, S., Kuś J. (2006). Regionalne zróżnicowanie produkcji roślinnej w Polsce na tle warunków przyrodniczych i ekonomiczno-organizacyjnych. Wieś Jutra, nr 6, s. 3-5.

Milewski, R. (red nauk.) (2008). Elementarne zagadnienia ekonomii. Warszawa: PWN, s. 187-188.

Popp, J., Hantos, K. (2011). The impact of crop protection on agricultural production. Studies in Agricultural Economics, nr 113, s. 47-66.

Runowski, H. (2002). Rozwój zrównoważony rolnictwa i gospodarstw rolniczych. W: Wieś i rolnictwo perspektywy rozwoju. Warszawa: IERiGŻ, IRWiR PAN, SGH, s. 139-156.

Samuelson, P.A., Nordhaus, W.D. (1995). Ekonomia 1. Warszawa: PWN, s. 704-713.

Skarzyńska, A., Goraj, L., Ziętek, I. (2005). Metodologia SGM „2002” dla typologii gospodarstw rolnych w Polsce. Program Wieloletni 2005-2009, nr 5, Warszawa IERiGŻ-PIB.

Skarżyńska, A. (2010). Zagadnienia metodyczne rachunku kosztów ekonomicznych na przykładzie działalności produkcji roślinnej. Zagadnienia Ekonomiki Rolnej, nr 3(324), s. 90-107.

Tubiello, F.N., Soussana, J.F, Howden, S.M. (2007). Crop and pasture response to climate change, PNAS, 104.

Zalewski, A. (2016a). Rynek środków ochrony roślin. W: Rynek środków produkcji dla rolnictwa. Warszawa: IERiGŻ-PIB, ARR, MRiRW, nr 43, s. 19-20.

Zalewski, A. (2016b). Światowy rynek nawozów mineralnych. W: Rynek środków produkcji dla rolnictwa. Warszawa: IERiGŻ-PIB, ARR, MRiRW, nr 43, s. 18.

Żak, A. (2016). Środki ochrony roślin a zmiany w środowisku naturalnym i ich wpływ na zdrowie człowieka. Zagadnienia Ekonomiki Rolnej, nr 1(246), s. 155-166. 
ALDONA SKARŻYŃSKA

Institute of Agricultural and Food Economics

- National Research Institute

Warsaw

\title{
TECHNICAL, ECONOMIC AND ENVIRONMENTAL EFFICIENCY OF PRODUCTION OF SELECTED PLANT PRODUCTS IN THE AGRICULTURAL POLISH REGIONS
}

\begin{abstract}
The article presents regional differences in the effectiveness of the technical, economic and environmental production of winter wheat, winter rye, spring barley, oilseed rape and sugar beet. The study used data collected in the system AGROKOSZTY and Polish FADN. To illustrate the changes in the results of the surveyed activities were analyzed data of four years. The measure of technical effectiveness was the productivity of factors of production (labor, land and capital), economic efficiency - profitability index, which expresses the ratio of production to economic costs. While the environmental efficiency describe indicators showing the cost and level of outlays adversely affecting the environment, ie. mineral fertilizers (NPK) and plant protection products.

The results show significant regional differences. The technical efficiency of production factors in farms located in the regions: Wielkopolska and Slask, Pomorze and Mazury was higher than in Mazowsze and Podlasie and in the region Małopolska and Pogórze. The smallest variation in regions characterized by the productivity of the land. Economic production efficiency ranged 97,1-147,5\%. Profitability index at the level of 97.1\% was guaranteed by rye in the region Malopolska and Pogórze, its height means that the economic costs are not fully covered. For full coverage of the economic costs would be necessary increase of yield of rye or increase of rye grain prices by $4.5 \%$. Regional differences in the applied dose of NPK fertilizers in the cultivation of rye was 1.4 times, and in the case of other crops - 1.1 times.

While the cost of plant protection products more varied regionally. Differentiation of 1.1-fold was observed only for sugar beet, in the case of wheat and barley were 1.2-fold, oilseed rape - 1.3-fold and rye-2.3-fold. In the region of Pomorze and Mazury and Wielkopolska and Ślask cost of pesticides and fertilizers NPK per 1 ha of surveyed activities it was mostly higher than in Mazowsze and Podlasie and the region Malopolska and Pogórze.
\end{abstract}

Keywords: technical efficiency of factors of production, production profitability, environmental performance, economic costs of agricultural products, management income.

Zaakceptowano do druku - Accepted for print: 10.03.2017.

0 ile nie jest to stwierdzone inaczej, wszystkie materiały na stronie są dostępne na licencji Creative Commons Uznanie Autorstwa 3.0 Polska. Pewne prawa zastrzeżone na rzecz Instytutu Ekonomiki Rolnictwa i Gospodarki Żywnościowej - PIB.

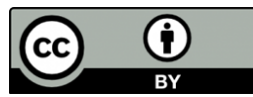

